\title{
Framework for assessing the viability of implementing dual water reticulation systems in South Africa
}

\author{
AA llemobade ${ }^{1 *}$, JR Adewumi ${ }^{1}$ and JE van Zyl ${ }^{2}$ \\ ${ }^{1}$ School of Civil and Environmental Engineering, University of the Witwatersrand, South Africa \\ ${ }^{2}$ Department of Civil Engineering Science, University of Johannesburg, South Africa
}

\begin{abstract}
In many settlements across the world (e.g. Pimpama Coomera and Mawson Lakes - Australia, Hong Kong - China, Majuro - Marshall Islands, Tarawa - Kiribati, and Windhoek - Namibia), dual water reticulation systems have been implemented in response to increasing water demands and decreasing freshwater availability. A dual water reticulation system comprises separate pipes that supply different water qualities to the end consumer. A set of pipes supply potable water while another set of pipes supply non-potable water. The non-potable water is targeted at meeting water requirements traditionally met using potable water (e.g. toilet and urinal flushing, landscaping irrigation, and industrial cooling). This therefore frees potable water to be used for previously unmet or increasing potable water requirements. For several reasons including the dearth of relevant national regulatory and guideline documents, consumer and decision-maker perceptions, ignorance, and appropriate decision-making tools, the use of dual water reticulation systems in South Africa has been limited. The aim of this study was therefore to develop a decision-making framework, using robust criteria, for assessing the viability of implementing dual systems in South Africa. This aim was achieved through undertaking literature reviews on the subject, an investigation of non-potable water consumers' and decision-makers' perceptions using questionnaires, and the actual development of a framework using data obtained from the literature review and questionnaires. The questionnaires were developed using seven key issues i.e. public health and safety, economics, technical feasibility, legislation/regulations and guidelines, organisational capacity, social acceptance, and public education. The various aspects of the Triple Bottom Line of sustainability (i.e. economic, environmental and social) provided structure to the framework while the Triple Bottom Line approach was utilised in the assessment of the different criteria.
\end{abstract}

Keywords: dual water reticulation systems, non-potable water recycling

\section{The South Africa water resources situation: background and motivation}

Water is increasingly becoming a limiting resource in South Africa and the scarcity of this resource affects national, provincial and local development in critical areas (Eberhard and Robinson, 2003). South Africa is an arid to semi-arid country with high water stress due to the low mean annual precipitation, MAP (which is approximately $500 \mathrm{~mm} / \mathrm{a}$ - significantly below the world average of about $860 \mathrm{~mm} / \mathrm{a}$ ) and high mean annual evaporation, MAE (approximately $350 \%$ of MAP) (Eberhard and Robinson, Ibid). Of interest is the highly seasonal occurrence of rainfall over virtually all of the country resulting in a wide range of climates, from winter rainfall and warm windy summers in the south-western Cape, to erratic, non-seasonal rainfall and extreme temperatures in the Karoo. The variation in annual rainfall from the long-term mean is especially pronounced in the more arid areas where unpredictable droughts of extended durations often contribute to the harshness of existing water scarcity. Also, as a consequence of topographical and climatic conditions, the natural availability of surface water across the country is unevenly distributed with more than $60 \%$ of run-

This paper was originally presented at the 2008 Water Institute of Southern Africa (WISA) Biennial Conference, Sun City, South Africa, 18-22 May 2008.

* To whom all correspondence should be addressed.

푱 +2711 7177153 ; fax: +2711 7177045 ;

e-mail: Adesola.Ilemobade@wits.ac.za off arising from $20 \%$ of the land area. In some places the runoff can be highly variable and below normal for up to 10 consecutive years (DWAF, 2004a).

Many of the metropolitan and industrial centres of South Africa (e.g. Johannesburg, Kimberley, Rustenburg, Mokopane, Durban and Cape Town) have developed around mineral deposits and harbour sites, and are located a significant distance away from major freshwater sources. Some irrigation developments in the country are also located in sub-optimal regions with respect to water use efficiency, having been established in times of relative water abundance and lower demand for water in upstream reaches. Thus, the location of several South African metropoles, industrial and agricultural areas has added to the challenges of freshwater availability.

To manage existing water resources, the country's hydrological basins have been divided into 19 water management areas with total available water resources of approximately $49 \times 10^{9}$ $\mathrm{m}^{3} / \mathrm{a}$. This includes water inflows of about $4.8 \times 10^{9} \mathrm{~m}^{3} / \mathrm{a}$ and 0.7 $\mathrm{x} 10^{9} \mathrm{~m}^{3} / \mathrm{a}$ originating from Lesotho and Swaziland respectively (DWAF, 2004a and Mukheibir, 2005). Of the total available water resources, only about $25 \%\left(13.23 \times 10^{9} \mathrm{~m}^{3} / \mathrm{a}\right)$ is harnessed as usable yield - this figure includes usable return flows, surface water and groundwater. Groundwater accounts for only about $2.2 \%$ of the total available water resources as the country is mainly underlain by hard rock formations which, although rich in minerals, do not contain major groundwater aquifers that can be used on a large scale for water supply (Mukheibir, 2005). The incidence of groundwater salinity in especially the coastal areas of the country also adds to the unavailability of fresh groundwater. Nevertheless, groundwater has played a pivotal role in the 
settlement and initial development of the country, and continues to do so, especially in rural areas of the country (Basson et al., 1997). Total water use in the year 2000 grouped into six categories, amounted to about $12.87 \times 10^{9} \mathrm{~m}^{3} / \mathrm{a}$ (a figure almost matching the exploitable supply) with the agricultural sector consuming the largest proportion of supply (62\%), while urban, mining and industry, rural, afforestation, and power generation sectors consuming $23 \%, 6 \%, 4 \%, 3 \%$ and $2 \%$ respectively (DWAF, 2004c).

The scenarios painted above have therefore resulted in dire water scarcity problems in several areas of South Africa, with the result that in several river catchments, the water requirements already far exceed the natural availability of water. It was projected in 1996 that the water resources supply for the country may be unable to cater for anticipated overall demands by 2030 if demands did not go unchecked (Basson et al., 1997). Supply and demand have thus had to be balanced by large water resources development projects (fresh and saline water) and extensive inter-basin transfers from areas of surplus to areas of deficit. Some water demand management initiatives (e.g. leakage management, meter management, use of efficient plumbing fittings and non-potable water use) have also been implemented. Non-potable water use has in particular, become an area of interest in recent times.

Potable water refers to water that is safe for human consumption while non-potable water refers to non-consumable water. Non-potable water, after some level of treatment, may be suitable for some water requirements e.g. toilet and urinal flushing, car washing, fire-fighting, landscape irrigation, dust suppression and a variety of industrial and commercial water requirements this process is called water recycling/reuse. Potable water, which is of a better quality and higher cost, is however, commonly used for these non-potable water requirements. This practice is unsustainable if South Africa is to effectively manage increasingly scarce freshwater resources.

Non-potable water conveyed through dual water reticulation systems (henceforth, dual systems) therefore presents a viable option to supplementing existing water supplies. This option is particularly promising for arid South African settlements with limited access to freshwater sources, still in the process of developing their basic infrastructure, in proximity to saline (i.e. brackish or sea) waters, and/or that generate significant volumes of rain water, storm water runoff, sewage, grey-water and/or mine effluent. Grey-water represents household wastewater from showers, baths, hand basins, laundry tubs, washing machines, dishwashers and kitchen sinks and does not include water from toilets.

In addition to aridity (discussed above), other factors encouraging non-potable water use in South Africa include (Ilemobade et al., 2008):

- The Growing demands for greener water strategies

- The heightened awareness of the potential nutritional benefits of using suitably treated sewage/grey water effluent (henceforth treated effluent) in the agricultural sector

- The high costs of supplying large quantities of potable water to arid areas. This is especially true for settlements distant from urban centres and with limited access to municipal water infrastructure.

\section{Literature review}

In arid regions of the world where there has traditionally been scarcity of water, treated effluent reuse has been successfully implemented e.g. Jordan (Al-Jayyousi, 2004), Israel (Friedler et al., 2006), Spain (March et al., 2004), Australia (Po et al., 2003; Po et al., 2005), Namibia (Van der Merwe, 2006), and some parts of South Africa (Sustainability Institute, 2006; CoCT, 2007b). Also, due to the advantages of implementing reuse to supplement potable water supplies, reuse has been embraced in some water rich countries such as China (Junying et al., 2004), Japan (Dixon et al., 1999), Germany (Nolde, 1999), United Kingdom (Jimenez and Asano, 2008) and the United States of America (Okun, 1996).

Internationally, different categories of dual water reticulation systems with diverse design specifications, conveying diverse non-potable water qualities for different water requirements, have been implemented. Many of these systems can be found in the United Kingdom, United States of America, Singapore and Australia (Dimitriadis, 2005; Po et al., 2005; Po et al., 2003), Namibia (van der Merwe, 2006), Japan, China (Tang et al., 2007), the Caribbean nations of Trinidad and Tobago (Business and Economy, 2003), Netherlands (Health Stream, 2003), and Republics of Kiribati and the Marshall Islands (Parr et al., 1997).

In South Africa, the use of dual systems was investigated in the past (Botha and Pretorius, 1998). The report concluded that dual systems offer new possibilities for maintaining adequate water supply and appropriate use of the available water resources in South Africa. Dual systems were reported to be especially beneficial in the following areas:

- Where sea or brackish water (with high total dissolved solids (TDS) concentrations) is the closest available water source;

- Where intensive indirect reuse of water may cause high Total Dissolved Solids concentrations in the source waters (as with the Vaal River barrage).

- Where the incremental cost of developing new freshwater sources may be high and therefore less attractive in comparison to recycling sewage effluent. The mass balances and cost comparisons conducted in Botha and Pretorius (1998) study indicated that using dual systems would result in smaller desalination streams, less salts to be removed from sewage, better water utilisation indices and probably, better economics than the reclamation of treated effluent for direct potable reuse.

Uptake of the recommendations of Botha and Pretorius (1998) study in especially arid settlements of South Africa has been limited, despite the fact that the technology surrounding dual systems and non-potable water use has evolved since then, with great strides made on the subject. Some international and local examples of the different categories of dual systems are presented below.

\section{Dual water reticulation systems for individual non-potable use}

Non-potable water generated by a household is collected on-site and then distributed using separate pipes for non-potable uses within the same household. Treatment and storage is dependent on local circumstances and the targeted water use(s).

- International examples include: residential toilet flushing and garden irrigation in Springfield (Queensland), the Sydney Olympic Park (Homebush Bay, New South Wales), and Mawson Lakes (South Australia), Australia using treated effluent and storm water runoff (Po et al., 2003 and Dimitriadis, 2005);

- South African examples include: garden irrigation in Hull street (Kimberley) using grey-water (Webster, 2006); and 
garden and crop irrigation in Carnarvon (Northern Cape) using grey-water (Ilemobade et al., 2008).

\section{Dual water reticulation systems for district non- potable use}

Non-potable water is collected at a central location from multiple buildings and then distributed using separate pipes for non-potable uses within the same or other buildings. These may include large housing developments comprising single and/or multiple storey buildings. Treatment and storage is dependent on local circumstances and the targeted water use(s).

- International examples include: supplying non-potable domestic requirements in the Hockerton housing scheme and the Beddington Zero Energy housing Development (BedZED) (South London), UK using harvested rain water (Heather, 2005)

- South African examples include: garden irrigation and toilet flushing in the Lynedoch Ecovillage (Stellenbosch) using treated effluent (Sustainability Institute, 2006); and toilet flushing using saline groundwater and landscape irrigation using treated effluent in Garies (Northern Cape) (Mvula Trust, 2006)

\section{Dual water reticulation systems for wide area urban/ agricultural non-potable use}

Non-potable water is collected at a central location from domestic and non-domestic sources and then treated, stored and distributed using separate pipes for non-potable domestic and/or non-domestic uses elsewhere. These dual systems may incorporate treated effluent supply from a sewage treatment works, STWs).

- International examples include: toilet flushing and fire fighting in Majuro (Marshall Islands) and Tarawa (Kiribati) using saline groundwater (Parr et al., 1997); toilet flushing in Hong Kong (China) using sea water (Tang et al., 2007); horticulture irrigation via the Virginia Pipeline Scheme at Bolivar (South Australia) using treated effluent (Po et al., 2003); residential toilet flushing, car washing, garden irrigation and fire fighting in Rouse Hill (New South Wales, Australia) and Pimpama Coomera (Gold Coast, Australia) using treated effluent (Po et al., 2003; Po et al., 2005); landscape irrigation in Windhoek (Namibia) using treated effluent (Van der Merwe, 2006); and landscape irrigation and carpet dyeing in the Irvine Ranch Water District (Orange County, USA) using treated effluent (IRWD, 2006)

- South African examples include: industrial and mining process water and landscape irrigation in the Rustenburg Local Municipality (North West), Mokopane and Potgietersrus (Limpopo), and the City of Cape Town, (henceforth CoCT) (Western Cape) using treated effluent (Jimenez and Asano, 2008 and CoCT, 2007b); and paper production in Mondi Paper (eThekweni, KwaZulu-Natal) using treated effluent (Jimenez and Asano, 2008);

\section{Dual water reticulation systems for industrial non- potable use}

Non-potable water which is generated from industrial use is collected on-site, treated, stored and distributed using separate pipes for on-site non-potable uses.

- International examples include: sugar and malt production, and beverage bottle washing in Germany using recycled process water (Jimenez and Asano, 2008)

- South African examples include: mining process water, toilet flushing and landscape irrigation in the Gold Fields gold mine in Driefontein (Gauteng) using treated effluent and recycled dolomite water (Ilemobade et al., 2008); industrial process water in Sasol (Sasolburg), AECI (Modderfontein), Nampak Tissue (Bellville) using treated process water (Jimenez and Asano, 2008)

\section{Methodology}

Considering the wealth of experience and significant potential for dual systems in South Africa, the aim of this study was to develop a decision-making framework, using robust criteria, for assessing the viability of implementing dual systems in potential South African settlements. Since governmental decision-making is critical when planning centralised schemes, the assessment framework must specifically apply to dual systems for district level, wide area urban/agricultural, and industrial non-potable use.

The aim of this study was achieved through undertaking three tasks, i.e.

- Literature surveys, which attempted to garner local and international experiences of dual systems

- Social surveys using questionnaires, on-site visits, and consultations, which collected and analysed perceptions of some non-potable water consumers and water services decision-makers

- The development of a framework for assessing the viability of implementing dual systems in South Africa. Methodology, results and discussion for the $2^{\text {nd }}$ and $3^{\text {rd }}$ tasks are presented separately in the sections below.

\section{Methodology for the social surveys}

A significant number of the early studies of public perceptions relating to water reuse were undertaken in the US. Most of these studies were limited in their scope which often aimed to increase public acceptance using applied behavioural methods (e.g. incentives). This early approach to implementing water reuse projects often viewed public acceptance as the principal 'obstacle' to implementing recycling projects. In the literature, this approach has been shown to be inadequate (Po et al., 2003; Po et al., 2005). Subsequent research following this view involved finding ways to persuade people to accept recycled water. It is now generally accepted that social marketing or persuasion is ineffective in influencing people to use non-potable water. The approach, however, of involving communities prior to the conception of the project has produced consistent results especially within developing settlements (Po et al., 2003; Po et al., 2005). Part of this approach, called the demand responsive approach, involves the early mining of trends, data and perceptions relating to the project. The data generated would then indicate to a large extent, the potential for success or failure of a reuse project. The social survey therefore adopted this approach in determining the perceptions of domestic respondents (most of whom were ignorant of plans to implement mine-water recycling in their area by the local authority), institutional consumers (all of whom utilised treated effluent), and decision-makers.

The Department of Water Affairs and Forestry, DWAF (2004b) has set a number of objectives against which strategies of water institutions or consumers (to influence water demand and use) should be measured. These are economic efficiency, social development, social equity, environmental protection, 


\begin{tabular}{|c|c|c|c|}
\hline \multicolumn{4}{|r|}{$\begin{array}{c}\text { TABLE } 1 \\
\text { Distribution of respondents }\end{array}$} \\
\hline Category & Respondents & $\begin{array}{l}\text { Number of } \\
\text { respondents }\end{array}$ & Description of respondents \\
\hline \multirow[t]{2}{*}{ Consumers } & Households & 68 & $\begin{array}{l}\text { Domestic consumers of potable water produced from recycled mine effluent in } \\
\text { Emahlaleni. The Emahlaleni settlement provided the opportunity to evaluate res- } \\
\text { idents' perceptions on the consumption of potable water from an unconventional } \\
\text { source, the use of non-potable water for non-potable water uses, and willingness } \\
\text { to adopt dual systems in homes. Three Emahlaleni settlements were surveyed: } \\
\text { Extension } 14-14 \text { respondents } \\
\text { Ackerville }-28 \text { respondents } \\
\text { Lynville }-26 \text { respondents }\end{array}$ \\
\hline & Institutions & 17 & $\begin{array}{l}\text { Institutional consumers of treated effluent at the Cities of Cape Town (Western } \\
\text { Cape) and Lephalale (Limpopo) include petroleum, pulp and paper, textile, con- } \\
\text { struction, mining and irrigation (public landscapes, sports fields, school fields, } \\
\text { crop) based organisations. }\end{array}$ \\
\hline \multirow[t]{3}{*}{$\begin{array}{l}\text { Decision- } \\
\text { makers }\end{array}$} & DWAF officials & 2 & $\begin{array}{l}\text { DWAF officials involved with non-potable water use and reticulation in South } \\
\text { Africa and based in Pretoria }\end{array}$ \\
\hline & $\begin{array}{l}\text { Treated effluent } \\
\text { service providers }\end{array}$ & 1 & Service providers of treated effluent at the CoCT \\
\hline & $\begin{array}{l}\text { Potable water } \\
\text { service providers }\end{array}$ & 8 & $\begin{array}{l}\text { Service providers of potable water in Johannesburg, Klerksdorp, Cannon Rocks } \\
\text { and Cape Town }\end{array}$ \\
\hline
\end{tabular}

sustainability of water supply and services, and political acceptability. Po et al. (2003) recommends, in addition to the objectives above, some factors that may influence the acceptance of a water reuse project, i.e. the disgust or 'yuck' factor; perceptions of risk associated with using recycled water; the specific uses of recycled water; the sources of water to be recycled; the issue of choice; trust in the service provider; knowledge of water reuse; attitudes towards the environment; environmental justice issues; the cost of recycled water; and socio-demographics. An in-depth analyses of these issues was expected to not only provide insights into potential consumers' and decision-makers' perceptions concerning non-potable water use, but also provide useful information for decision-making.

The questionnaires, which may be accessed from Ilemobade et al. (2008), were developed using the following key issues (which summarise the DWAF (2004b) objectives and Po et al. (2003) factors):

- Economic efficiency

- Technical feasibility

- Social acceptance

- Organisational capacity

- Availability of appropriate legislation/regulations and guidelines

- Public health and safety and public education.

The questionnaires were then administered to some technical and non-technical water supply decision-makers and consumers (Table 1). The data generated and analysed was then used to develop the decision-making framework. The development of the framework is discussed in a later section.

\section{Results and discussion on the social surveys}

\section{Economic efficiency and technical feasibility}

- A significant percentage (56\%) of institutions consuming treated effluent in the CoCT are located within a radius of $500 \mathrm{~m}$ from the STWs (Fig. 1). For distances greater than $500 \mathrm{~m}$, fewer institutions use treated effluent. This is primarily due to the high costs of installing long-distance distribution pipelines and the recurrent costs of supplying potential consumers with treated effluent.

- For domestic respondents, although initial willingness to use treated mine effluent was low at $36 \%$, the supply of treated mine effluent at tariff lower than the potable water tariff significantly influenced respondents' willingness (71\%) to embrace treated mine effluent reuse (Fig. 2). This is further proven by respondents' response (a decrease in willingness from $71 \%$ to $15 \%$ ) to using the treated mine effluent if the tariff was higher than the potable water tariff. Therefore, for dual systems to be widely accepted in South Africa, non-potable tariffs must be significantly lower than potable water tariffs.

- Figure 2 also shows that colour coding and proper labelling of non-potable pipes played a significant role in encouraging domestic respondents to accept dual systems.

- An important factor that has impacted on treated effluent reuse amongst institutional respondents is the effluent quality supplied them from the participating STWs. Effluent quality is largely influenced by influent quality and

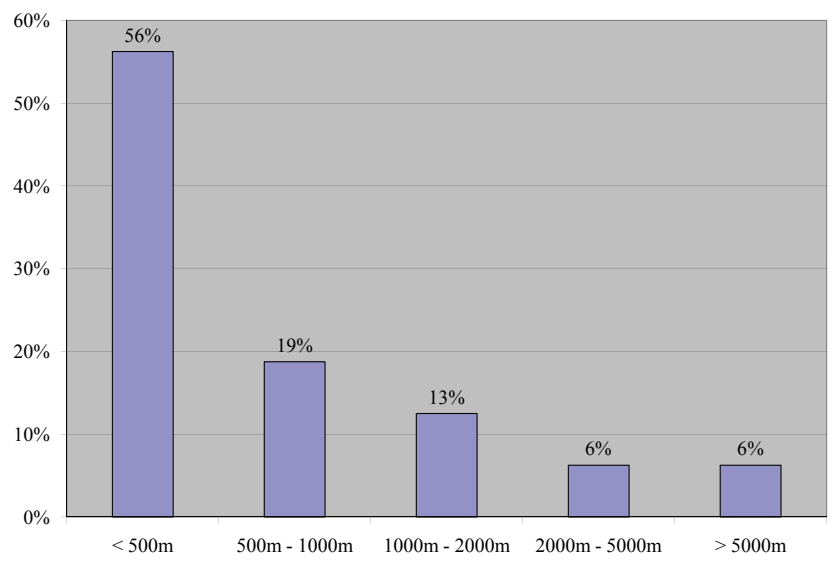

Figure 1

Distance of treated effluent from institutional consumers 


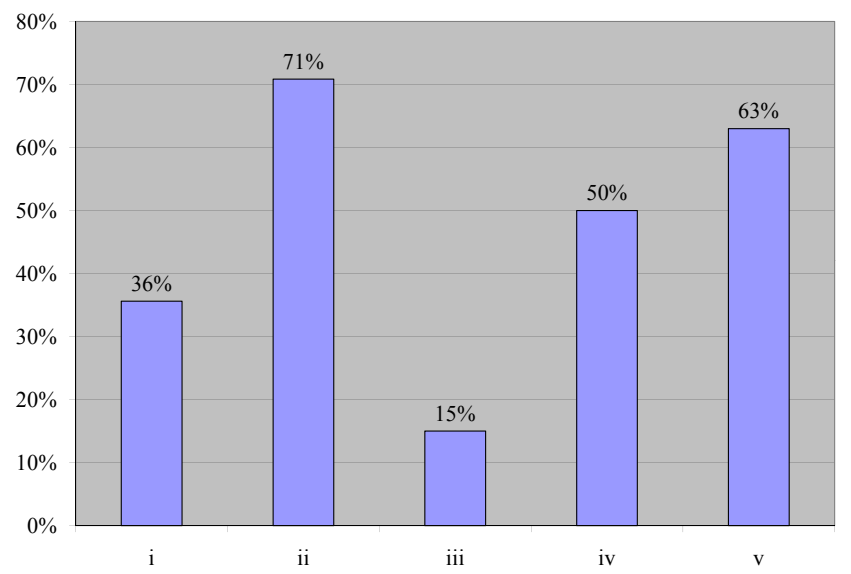

Legend

i Initial willingness to use treated mine effluent

ii Willingness to use treated mine effluent if the tariff is less than the potable water tariff

iii Willingness to use treated mine effluent if the tariff is more than the potable water tariff

iv Interested in installing a dual system in your house?

$\mathrm{v}$ Interested in a dual system in your house if it is colour-coded and properly labelled?

\section{Figure 2}

Non-potable water tariff and interest in installing a household dual system

treatment works efficiency. Due to highly toxic influents (especially from industrial sewage) and sub-optimal STWs efficiencies, many of the participating STWs regularly fail to produce treated effluent of the prescribed quality. For this reason, all institutional consumers (excluding those using treated effluent for irrigation) undertook further on-site treatment of the effluent before reuse.

- The use of recycled water for applications that may involve human contact or ingestion generally attracts opposition from potential users (Po et al., 2003; Dimitriadis, 2005). Hence, amongst domestic respondents, the most widely accepted options for non-potable water use were those requiring minimal human contact i.e. toilet flushing, car washing and landscape irrigation (Fig. 3). For non-domestic non-potable uses, decision-makers indicated their highest preferences for landscape and crop irrigation.

\section{Social acceptance}

- If a period of water shortage were to be experienced, $94 \%$ of consumers would consider water reuse (Fig. 4). However, about a third $(26 \%)$ of consumers thought recycling water was disgusting. A disgust reaction is likely to be generated from people's perceived 'dirtiness' of the water and their fear of contagious diseases from using the water. Despite the high percentage of respondents recommending recycled water use and the low percentage of disgust, $64 \%$ of consumers indicated that they were not willing to use the recycled water. This may be because the consumers saw the logic in reuse, but when confronted about their willingness, immediately felt that they could not use the water. It is therefore of utmost importance that decision-makers give priority to this issue. Neglect may result in a failed reuse project.

- Consumers' trust in the Water Service Provider to supply the appropriate quality of recycled water was $48 \%$ (Fig. 4). This response is poor and unfortunate and may likely be

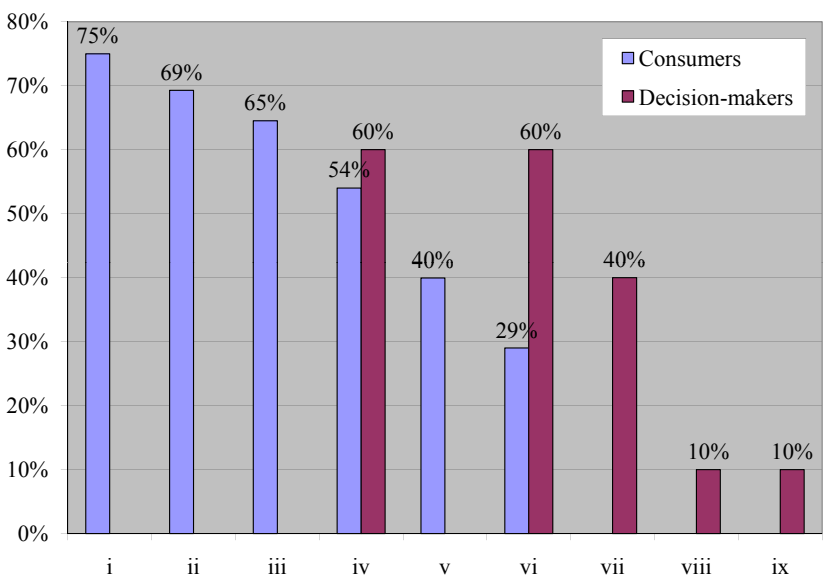

Legend

i Recycled water is appropriate for non-potable uses if treated appropriately

ii Willing to use treated effluent for toilet flushing

iii Willing to use treated effluent for car washing

iv Willing to use treated effluent for landscape irrigation

v Willing to use treated effluent for laundry

vi Willing to use treated effluent for vegetable/crop/fruit irrigation vii Willing to use treated effluent for manufacturing viii Willing to use treated effluent for refinery processes

ix Willing to use treated effluent for dust suspension

Figure 3

Consumers' preferences for reused water

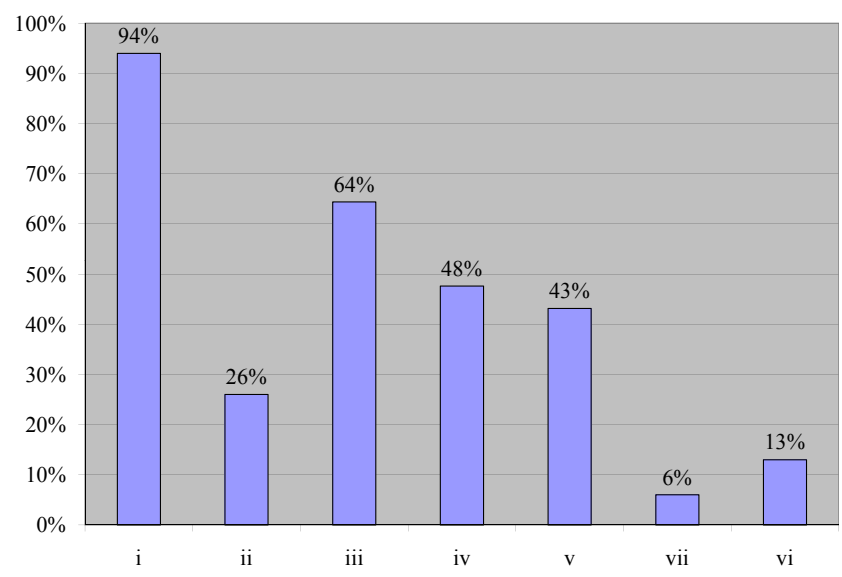

Legend

i I will recommend recycled water reuse during a drought

ii Recycled water is disgusting

iii Not willing to use recycled water

iv I trust the municipality to supply the appropriate quality

v Not willing to use recycled water even if quality assured by the local authority

vi I know of disease outbreaks due to recycled water reuse (CoCT respondents only)

vii Risks are high when using recycled water (CoCT respondents only)

Figure 4

Social acceptance of non-potable water use

influenced by incidences of illnesses and death directly attributable to poor potable water qualities in settlements such as Delmas (Mail and Guardian, 2007) and the Ukhahlamba District Municipality (News24.com, 2008). There is 
however a decrease in the percentage of consumers unwilling to use the effluent (from $64 \%$ to $43 \%$ ) if the quality is assured by the local authority.

\section{Public health and safety}

- One institutional respondent in the CoCT (representing $6 \%$ of the respondents from the CoCT) indicated that they know of disease outbreaks due to treated effluent reuse (Fig. 4). This has therefore resulted in $13 \%$ of these respondents considering the potential risks to be low. For any dual system to gain public confidence and acceptance, the risk of disease must be minimal. In the CoCT, the low incidence of accidental consumption and disease may be attributed to the fact that the use of treated effluent has been restricted to non-domestic purposes with very low potential for human contact. It is likely that perceptions of potential risks will change if treated effluent is considered for domestic use which has higher potential for human contact (Friedler et al., 2006).

- Domestic respondents expressed concerns about the safety of children when exposed to non-potable water. As a result, acceptance of a dual system may increase if child and general safety are assured.

- Perceptions of risk related to the consumption of fruits and vegetables irrigated with non-potable water were significant (above 50\%) (Fig. 5). This confirms the discussion presented on Figs. 3 and 4 - that the most widely accepted options for non-potable water will be those requiring minimal human contact.

- In general, all respondents showed high degrees of responsibility and concern for environmental protection and preservation (Figs. 5 and 6) through non-potable use. This therefore reiterates that respondents were generally disposed to use non-potable water under specific circumstances.

\section{Legislation/regulations and guidelines}

Below are three of the regulatory clauses that briefly and broadly address grey-water and treated effluent quality and reuse in South Africa. In these documents, there is no objection to the reuse of grey water or treated effluent provided it is permitted and monitored by the relevant water services authority. Because of the brevity of these clauses, they do not address dual water reticulation systems and therefore, there are no national guideline documents on the implementation of dual systems.

- Government Gazette No. 9225, Regulation 991: Requirements for the purification of wastewater or effluent (EAF, 1984)

- The latest revision of the Water Services Act of 1997 relating to grey-water and treated effluent (DWAF, 2001)

- The latest revision of the National Water Act of 1998, 37(1) (DWAF, 2004a) relating to irrigation of any land with waste or water containing waste generated through any industrial activity or by a water works.

There are, however, some detailed guideline documents on non-potable water use. Specifically, The South African Guide for the Permissible Utilisation and Disposal of Treated Effluent (DNHPD, 1978) and The South African Water Quality Guidelines (DWAF, 1996). The DWAF (1996) guidelines recommend the different water quality parameters required for various industrial, agricultural and aquatic eco-system water requirements irrespective of the water source, while the DNHPD (1978) guideline is specific to the use and disposal of treated effluent.

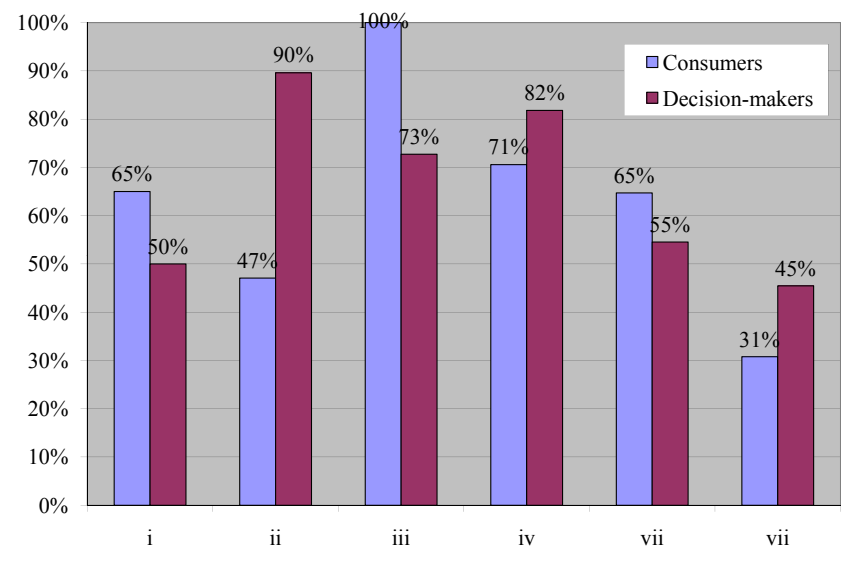

Legend

i Consumers have the right to know that the fruits and vegetables they are buying are irrigated with recycled wastewater

ii Water is a valuable resource that should be recycled

iii Non-potable water use can assist many drought- prone settlements

iv Non-potable water use reduces depletion of groundwater and surface water resources

v Non-potable water use reduces the quantity of wastewater discharged to the environment

vi Considerable fertiliser savings result on farms irrigated with treated effluent

Figure 5

Public health and safety concerns and environmental responsibility

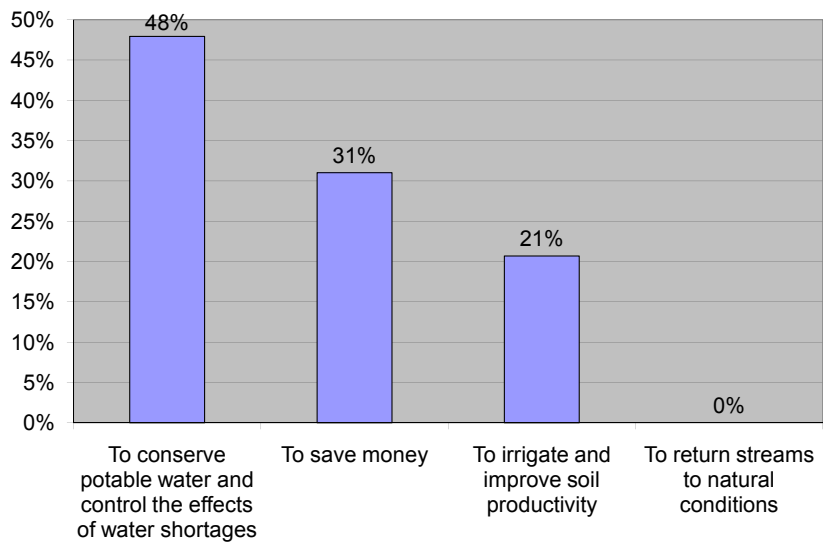

Figure 6

Reasons why institutional consumers were using treated effluent

The DNHPD (1978) guideline is currently more than 30 yrs old and promotes the concept of 'No potential risk' when using treated effluent. As a result, it involves high technology and is therefore a high-cost guideline. This guideline may therefore be largely inappropriate for low- to middle-income South African settlements with potential to use non-potable water.

\section{Public education}

Empowering communities through involvement, interaction and education is a valuable step in facilitating that community's acceptance of a dual system.

\section{Methodology for development of the framework}

A holistic decision-making framework should ideally incorporate the various aspects of the triple bottom line (TBL) of 


\begin{tabular}{|l|c|c|c|c|}
\hline \multicolumn{5}{|c|}{ TABLE 2 } \\
Ranking of key issues when planning a dual water reticulation system * \\
\hline Key issues & $\begin{array}{c}\text { Consumers' } \\
\text { ranking }\end{array}$ & $\begin{array}{c}\text { Decision-mak- } \\
\text { ers' ranking }\end{array}$ & Overall ranking & Overall weight \\
\hline Public health and safety & 1 & 2 & 1 & 1.00 \\
\hline Economics & 2 & 3 & 2 & 1.16 \\
\hline Technical / Engineering & 5 & 1 & 3 & 2.09 \\
\hline Legislation & 3 & 5 & 4 & 2.28 \\
\hline Organisational capacity & 4 & 6 & 5 & 2.44 \\
\hline Social acceptance & 7 & 4 & 6 & 2.84 \\
\hline Public education & 6 & 7 & 7 & 2.85 \\
\hline
\end{tabular}

* 1 represents most important while 7 is least important

sustainability, i.e. technical and economic; social, institutional and legal; and environmental and public health and safety (Jimenez and Asano, 2008; DWAF, 2004b). Traditional decisionmaking tools tend to focus on quantifiable factors (especially cost), leaving out equally important, yet mostly non-quantifiable factors that may have a significant influence on the project. The analysis of quantifiable and non-quantifiable factors will assist in casting a wider net to identify important issues that may significantly influence or impact a project.

The 7 key issues employed in the social surveys formed the backbone for the framework, with each key issue generating a list of items to be evaluated. The framework was categorised using the different aspects of the TBL of sustainability. Weights were allocated to each of the key issues based on the weighted average rank allocated by respondents when asked to rank the seven key issues in order of importance when planning a dual system (Table 2). These weights determined the level of importance given to the key issues within the framework. From Table 2 , it is interesting to note that consumers gave higher priorities to key issues which are traditionally high on decision-makers' priorities (i.e. public health and safety, economics, etc.). As such, issues that are very important to consumers such as social acceptance and public education were ranked the least important. It is important to note that several reuse projects (e.g. the Dublin County Clean Water Revival Project, California) have failed in the past due to the lack of social acceptance (Po et al., 2003) and as such, decision-makers must pay adequate attention to social acceptance and public education especially for a reuse project.
A schematic flow chart of the assessment process using the framework within the context of other potential water supply and/or demand options is shown in Fig. 7.

The TBL approach is employed in the evaluation of each aspect within the framework. The TBL approach provides a robust structure for evaluating alternatives and is designed to provide decision-makers with a framework to understand costs, benefits, impacts, risks, etc. of different alternatives. In this way, a more balanced view is created rather than one that relies on only quantifiable factors. It also allows decision makers to vary or weigh different items/criteria to discover those criteria that have the greatest influence on differentiating alternatives (CRD, 2007).

The TBL approach utilises the following: goals to be achieved; criteria which determine whether the goals are achieved; evaluation questions/statements by which each criterion is measured; and a range of scores for measuring each evaluation question/statement. Any number of goals and criteria can be selected. In developing the goals and criteria, a number of important rules, which facilitate an objective approach to achieving the goals for each aspect of the TBL, were followed, i.e. each goal and its criteria must be independent; non-duplicative; measurable; and exhaustive.

Tables 3, 4 and 5 show the framework developed for assessing the viability of implementing dual systems in South Africa based on the TBL approach and the data generated using the questionnaires, on-site visits, literature and consultations.

The framework was employed to practically assess the viability of implementing a dual water reticulation system within the
Figure 7 Schematic flow chart for assessing the viability of implementing dual systems

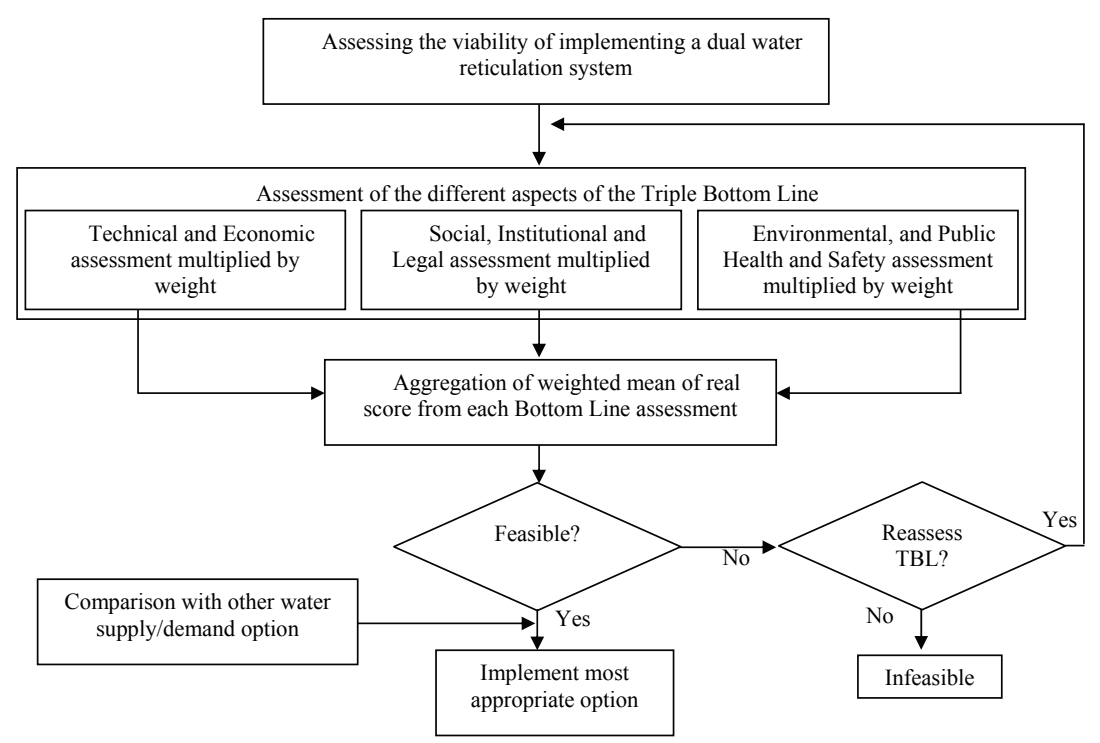

Available on website http://www.wrc.org.za 


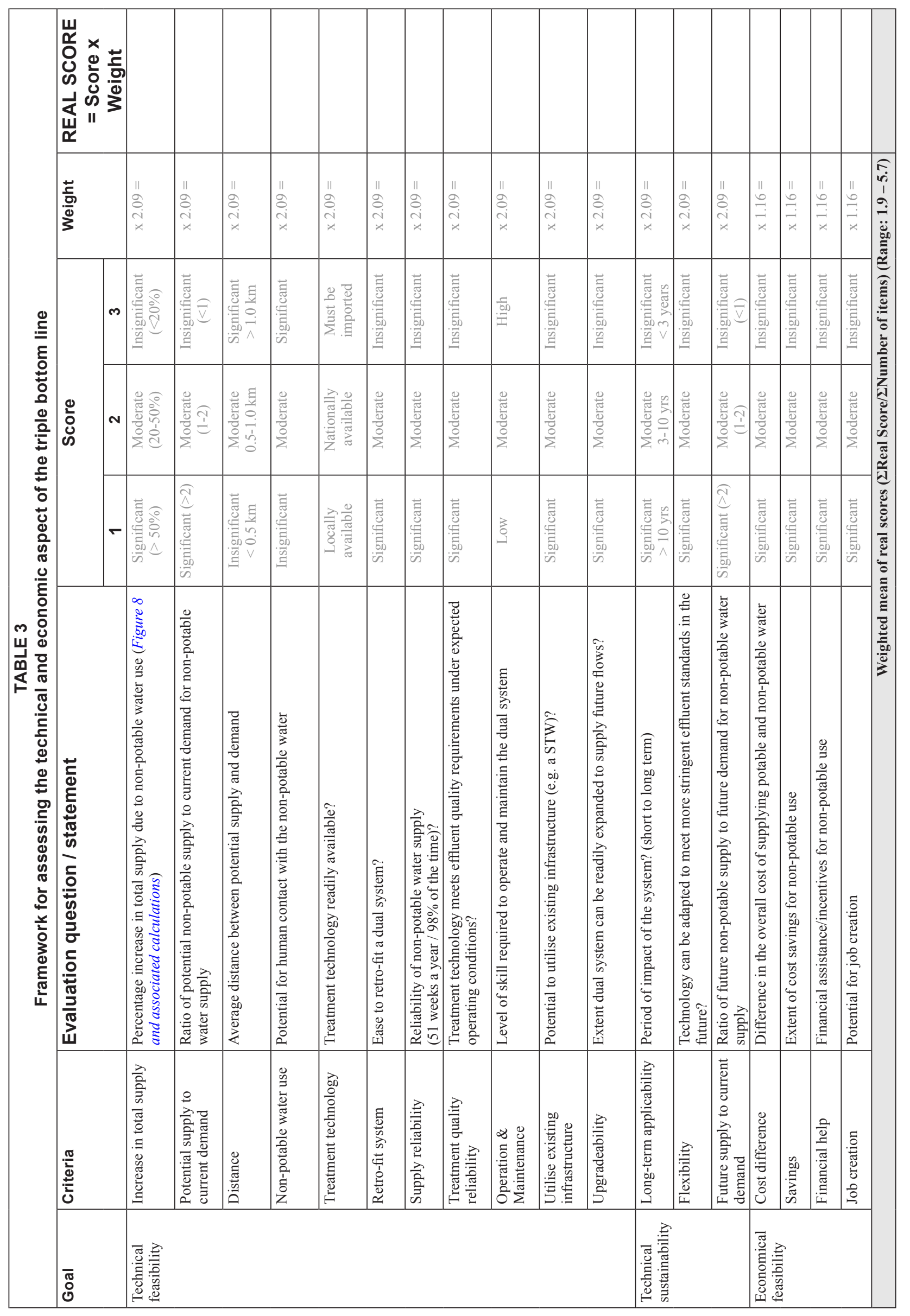


Figure 8

A schematic mass

balance of an

urban water system

incorporating reuse

(Grobicki and

Cohen, 1999)

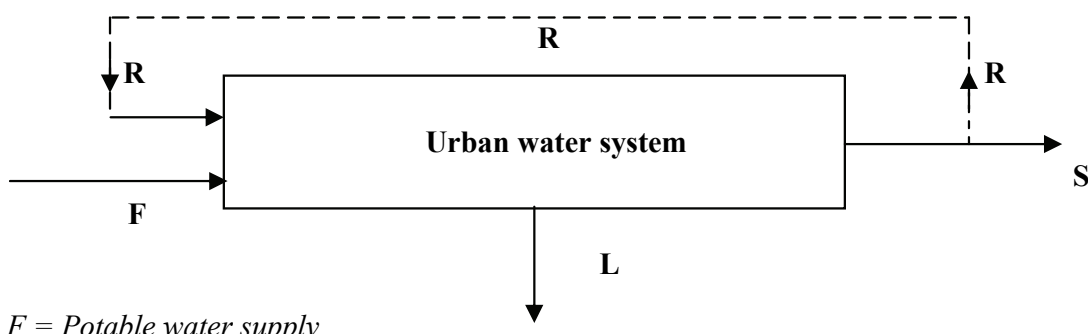

where $F=$ Potable water supply

$R=$ Recycled water supply

$L=$ Losses (e.g. leakage and evaporation)

$S=$ Effluent discharge
Gold Fields Gold Mine in Driefontein (Gauteng). Detailed results and discussion of the assessment are presented in Ilemobade et al. (2008). In the exercise, the framework facilitated a holistic assessment of the different criteria that are necessary to be considered prior to the implementation of a dual system.

\section{Percentage increase in total supply due to non-potable water use}

The first evaluation statement in Table 3 requires an assessment of the percentage increase in total supply due to nonpotable water use. This section provides a guide to calculating this percentage.

Grobicki and Cohen (1999) proposed an urban water-demand model for water reuse potential in South Africa (Fig. 8).

A water balance equation for the urban water system represented in Fig. 8 is:

$$
F+R=L+S+R
$$

Prior to calculating the percentage increase in total supply due to non-potable water use, the quantities of each of the variables in Eq. (1) must be determined for the water system being considered.

In the CoCT for example (CoCT, 2007a), $F=1180 \mathrm{M} \ell / \mathrm{d}, S=$ $563.07 \mathrm{M} \ell / \mathrm{d}$ and $R=80.50 \mathrm{M \ell} / \mathrm{d}$. For the CoCT therefore, Eq. (1) becomes:

$$
1180+80.50=L+563.07+80.50
$$

Summing the different values and rearranging, Eq. (2) becomes:

$$
L=616.93 \text { (i.e. } 48.94 \% \text { of } F+R \text { ) }
$$

With $L=49 \%$ of $F+R$ and assuming that all effluent is recycled (i.e. effluent discharge, $S=0$ ), Eq. (1) becomes

$$
R=1.04 F
$$

By substituting Eq. (4) into the left-hand side of Eq. (1), Eq. (1) becomes

$$
2.04 F=L+R
$$

Equation (5) implies that with Losses, $L$ equal to $49 \%$ of total supply and all effluent recycled (i.e. effluent discharge, $S=0$ ), the percentage increase in total supply due to non-potable water use would be $104 \%$.

\section{Conclusion}

For several reasons including the dearth of relevant regulatory and guideline documents, consumer and decision-maker perceptions, ignorance, and the lack of appropriate decision-making

\begin{tabular}{|c|c|c|c|c|c|c|c|}
\hline Fra & mework for & $\begin{array}{l}\text { TABLE } \\
\text { Issessing the social, institutional a }\end{array}$ & legislati & aspect & f the tripl & bottom & \\
\hline Goal & Criteria & Evaluation question / statement & & Score & & Weight & Real \\
\hline & & & 1 & 2 & 3 & & 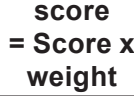 \\
\hline & Disgust & Extent of 'disgust' to non-potable water use & Insignificant & Moderate & Significant & $\times 2.84=$ & \\
\hline & Acceptance $^{* *}$ & $\begin{array}{l}\text { Acceptance of the dual system by the } \\
\text { community }\end{array}$ & Significant & Moderate & $\begin{array}{l}\text { Insignifi- } \\
\text { cant }\end{array}$ & $x 2.84=$ & \\
\hline $\begin{array}{l}\text { Social } \\
\text { feasibility }\end{array}$ & Aesthetics & $\begin{array}{l}\text { Unpleasant sight, noise and/or odour } \\
\text { emissions from the system }\end{array}$ & Insignificant & Moderate & Significant & $x 2.84=$ & \\
\hline & $\begin{array}{l}\text { Trust/confi- } \\
\text { dence in serv- } \\
\text { ice provider }\end{array}$ & $\begin{array}{l}\text { Consumers' level of trust and confidence in } \\
\text { the potable water service provider }\end{array}$ & High & Moderate & Low & $\times 2.84=$ & \\
\hline Institutional & Local capacity & $\begin{array}{l}\text { Availability of Institutional capacity to } \\
\text { operate the system }\end{array}$ & Significant & Moderate & $\begin{array}{c}\text { Insignifi- } \\
\text { cant }\end{array}$ & $\times 2.44=$ & \\
\hline feasibility & Acceptance $^{* *}$ & $\begin{array}{l}\text { Acceptance of the dual system by decision } \\
\text { makers }\end{array}$ & Significant & Moderate & $\begin{array}{c}\text { Insignifi- } \\
\text { cant }\end{array}$ & $\times 2.44=$ & \\
\hline $\begin{array}{l}\text { Legislative } \\
\text { availability }\end{array}$ & $\begin{array}{l}\text { Legislation / } \\
\text { Regulation }\end{array}$ & $\begin{array}{l}\text { Municipal Regulations/by-laws available to } \\
\text { guide system planning and operation }\end{array}$ & Significant & Moderate & $\begin{array}{c}\text { Insignifi- } \\
\text { cant }\end{array}$ & $\times 2.28=$ & \\
\hline Weighted me & an of Real Scor & ( $\Sigma$ Real Score $/ \Sigma$ Number of items) (Range: 2.7 & & & & & \\
\hline
\end{tabular}
tools, the prevalence of dual water reticulation systems has been limited in South Africa. Considering the wealth of international experience and the significant potential for implementing dual systems in South Africa, the aim of this study was to develop a

${ }^{* *}$ A score of 1 for this evaluation statement may likely render the project infeasible 


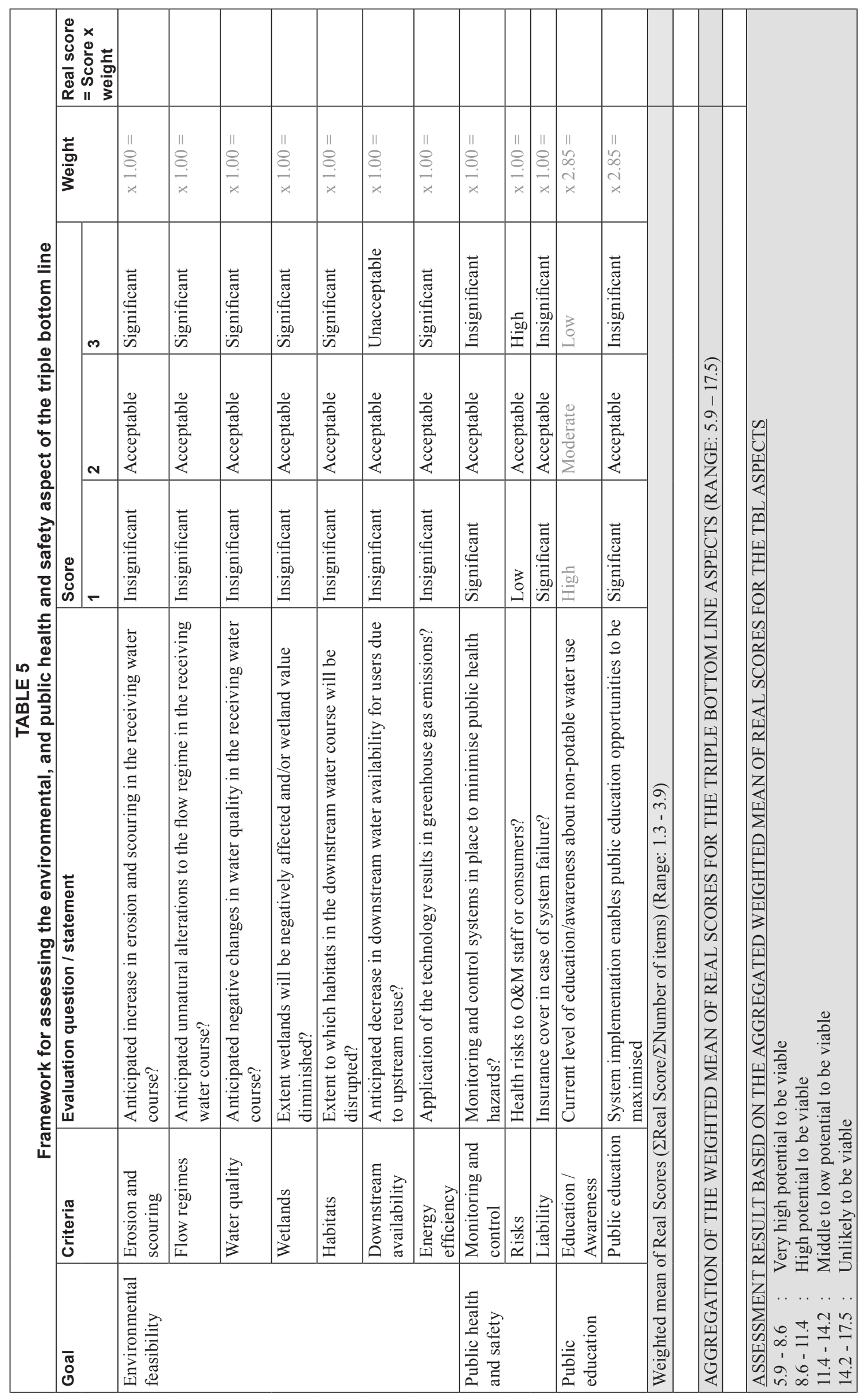


decision-making framework, using robust criteria, for assessing the viability of implementing dual systems in potential South African settlements. In achieving this aim, this study reviews literature on the subject and investigates, using questionnaires, the perceptions of some households in Emahlaleni and institutions in the CoCT and Lephalale (non-potable water consumers), and water and wastewater services providers and DWAF officials (decision-makers) in several South African local authorities. The questionnaires were developed using the objectives and factors recommended by DWAF (2004b) and Po et al. (2003) respectively. In order of priority dictated by the respondents, these objectives and factors are:

- Public health and safety (i.e. the potential for ill-health due to non-potable water use)

- Economics (i.e. non-potable water tariffs in comparison to potable tariffs)

- Technical feasibility (i.e. the aridity of the area, potential consumers distance from the non-potable water source, the quality of the raw non-potable water, proper labelling of the different components of the dual system, and the potential non-potable water uses)

- Availability of appropriate legislation/regulations and guidelines

- Organisational capacity

- Social acceptance (i.e. willingness to use non-potable water and potential consumers' trust in existing water services providers)

- Public education (i.e. empowerment of potential users).

The 7 key issues above, categorised using the different aspects of the TBL of sustainability (i.e. economic, environmental and social), formed the basis for the developed framework. Each key issue was represented by a list of items which were generated during the surveys. Weights, which indicated level of importance, were assigned to each issue and were based on the weighted average rank allocated by respondents. The TBL approach was then employed in the assessment of the different items. A scale of the aggregated weighted mean of real scores was provided to assist in the overall assessment of the viability of implementing a dual system with 5.90 representing very high potential to be viable and 17.50 representing unlikely to be viable.

\section{Acknowledgements}

The authors appreciate financial support from the Water Research Commission (Project No. K5/1701)

\section{References}

AL-JAYYOUSI OR (2004) Greywater reuse: knowledge management for sustainability. Desalination 167 27-37.

BASSON MS, VAN NIEKERK PH and VAN ROOYEN JA (1997) Overview of Water Resources Availability and Utilisation in South Africa. Department of Water Affairs and Forestry, DWAF Report P RSA/00/0197. CTP Book Printers, Cape Town, South Africa.

BOTHA J and PRETORIUS WA (1998) Die Uitvoerbaarheid van Dubbelwatervoorsieningstelsels. WRC Report No. KV 113/98. Water Research Commission, Pretoria, South Africa.

BUSINESS and ECONOMY (2003) Quenching a Global Thirst. Japanese Researchers Help to Combat Water Shortages. June 26. http:// web-japan.org/trends/business/bus030626.html (Accessed $24 \mathrm{Feb}$ 2006).

CoCT, THE CITY OF CAPE TOWN (2007a) Treated Effluent Re-Use Strategy and Master Planning within the City of Cape Town. BVi Report No. C1500/1.1. The City of Cape Town, South Africa.
CoCT, THE CITY OF CAPE TOWN (2007b) Water Services Development Plan 2007. The City of Cape Town, South Africa.

CRD, CAPITAL REGIONAL DISTRICT (2007) Core Area and West Shore Sewage Treatment. Discussion Paper No. 1-4. http://www.crd. bc.ca/ (Accessed 21 March 2007).

DIMITRIADIS S (2005) Issues encountered in advancing Australia's water recycling schemes. Research Brief, Parliamentary Library, Parliament of Australia, No. 2. Department of Parliamentary Services, Australia. ISSN 18322883.

DIXON A, BUTLER D and FEWKES A (1999) Water saving potential of domestic water reuse systems using greywater and rainwater combination. Water Sci. Technol. 39 25-32.

DNHPD (DEPARTMENT OF NATIONAL HEALTH AND POPULATION DEVELOPMENT) (1978) Guide: Permissible Utilization and Disposal of Treated Sewage Effluent. Report No. 11/2/5/3. Department Of National Health And Population Development, Pretoria, South Africa.

DWAF (DEPARTMENT OF WATER AFFAIRS AND FORESTRY) (1996) South African Water Quality Guidelines (3-7. $2^{\text {nd }}$ edn.). Pretoria, South Africa.

DWAF (DEPARTMENT OF WATER AFFAIRS AND FORESTRY) (2001) Regulation Gazette No. 7079. http://www.info.gov.za/gazette/ regulation/2001/22355.pdf (Accessed 29 Nov 2006).

DWAF (DEPARTMENT OF WATER AFFAIRS AND FORESTRY) (2004a) Revision of General Authorisations in Terms of Section 39 of the National Water Act 1998 (Act No 36 of 1998) - Engaging in a Controlled Activity. Government Gazette No. 26187. Pretoria, South Africa.

DWAF (DEPARTMENT OF WATER AFFAIRS AND FORESTRY) (2004b) DWAF's framework and Checklist for the Development of Water Services Development Plans. Department of Water Affairs and Forestry, Pretoria, South Africa.

DWAF (DEPARTMENT OF WATER AFFAIRS AND FORESTRY) (2004c) National Water Resource Strategy. Department of Water Affairs and Forestry, Pretoria, South Africa.

EBERHARD R and ROBINSON P (2003) Guidelines for the Development of National Water Policies and Strategies to support IWRM. Draft. SADC Water Sector Co-ordination Unit, Gaborone, Botswana.

EAF, MINISTRY OF ENVIRONMENTAL AFFAIRS AND FISHERIES (1984) Requirements for the purification of waste water or effluent. Government Gazette No. 9225, Regulation 991. Pretoria, South Africa.

FRIEDLER E, LAHAV E, JIZHAKI H and LAHAV T (2006) Study of urban population attitudes towards various wastewater reuse options: Israel as a case study. J. Environ. Manage. 81 360-370.

GROBICKI A and COHEN B (1999) Water Reclamation for Direct ReUse in Urban and Industrial Applications in South Africa and its Projected Impact upon Water Demand. WRC Report No. KV 118/99. Water Research Commission, Pretoria, South Africa.

HEATHER L (2005) Supply and Demand for Low Energy Housing in the UK: Insights from a Science and Technology Studies Approach. Housing Stud. 20 (5) 815-829.

HEALTH STREAM (2003). Setback for Netherlands dual supplies. Cooperative Research Centre for Water Quality and Treatment. Issue 30. June. http://www.waterquality.crc.org.au/hsarch/HS30d. htm (Accessed 13 Oct 2006).

ILEMOBADE AA, ADEWUMI JR and VAN ZYL JE (2008) Assessment of the Feasibility of using a Dual Water Reticulation System in South Africa. WRC Report No. K5/1701. Water Research Commission, Pretoria, South Africa.

IRWD, IRVINE RANCH WATER DISTRICT (2006) Water Reclamation. http://www.irwd.com/Reclamation/index.php (Accessed 22 Nov. 2006).

JIMENEZ B and ASANO T (2008) Water Reuse. An International Survey of Current Practice, Issues and Needs. Technical report No. 20. International Water Association (IWA). ISBN 1843390892.

JUNYING C, JINING C, CAN W and PING F (2004) Wastewater reuse potential analysis: implications for China water resources management. Water Res. 38 2746-2756. 
MAIL and GUARDIAN (M \& G) (2007) Over 500 Suffering from Diarrhoea in Delmas. Nov 9. http://www.mg.co.za/article/2007-11 -09-over-500-suffering-from-diarrhoea-in-delmas (Accessed 12 September 2008)

MARCH JG, GUAL M AND OROZCO F (2004) Experience on greywater reuse for toilet flushing in a hotel. Desalination 164 241-247.

MUKHEIBIR P (2005) Local water resource management strategies for adaptation to climate induced impacts in South Africa. Proc. Workshop on Rural Development and the Role of Food, Water and Biomass: Opportunities for Development and Climate. 14-16 November 2005, Dakar, Senegal.

MVULA TRUST (2006) Prioritising Planning: The Importance of Water Services Development Plans and Integrated Plans. http:// www.mvula.co.za/page/467 (Assessed 19 March 2007).

NEWS24.COM (2008) Unsafe water kills 80 kids. 22 April. http://www. news24.com/news24/south africa/news/0,2-7-1442 2310451,00. html (Accessed 12 September 2008).

NOLDE E (1999) Greywater reuse systems for toilet flushing in multistorey buildings - over ten years experience in Berlin. Urban Water 1 275-284.

OKUN DA (1996) Distributing reclaimed water through dual systems. J. Am. Water Works Assoc. 89 52-64.
PARR J, SMITH MD and STEAR RM (1997) Decreasing freshwater demand: dual supply systems. Proc. of the 23rd WEDC Conference. September 1997, Durban, South Africa. 404-406.

PO M, KAERCHER JD and NANCARROW BE (2003) Literature Review of Factors Influencing Public Perceptions of Water Reuse. Technical Report 54/03. CSIRO Land and Water.

PO M, NANCARROW BE, LEVISTON Z, PORTER NB, SYME GJ and KAERCHER JD (2005) Predicting Community Behaviour in Relation to Wastewater Reuse: What Drives Decisions to Accept or Reject? Water for a Healthy Country National Research Flagship. CSIRO Land and Water. Perth, Australia.

SUSTAINABILITY INSTITUTE (2006) Lynedoch Ecovillage. http:// www.sustainabilityinstitute.net/index.php. Accessed 13 August 2006.

TANG SL, DEREK PTY and DAMIEN CCK (2007) Engineering and Costs of Dual Water Supply Systems. IWA, UK. ISBN 1843391325.

VAN DER MERWE B (2006) Water reuse in Windhoek through a dual pipe system and artificial recharge of the aquifer. Proc. Int. Water Reuse Workshop organized by the Water and Wastewater Agency. 17-19 May, Tijuana, Baja California, Mexico.

WEBSTER E (2006) Life on Hull Street: sorting out sanitation. Dry sanitation and grey water. WASE (Water Sewage and Effluent) Africa 26 (2) 18-23. 